\title{
Metabolism of formestane in humans: Identification of urinary biomarkers for antidoping analysis
}

\author{
X. de la Torre ${ }^{a, *}$, D. Martinez Brito ${ }^{a}$, C. Colamonici ${ }^{a}$, M.K. Parr ${ }^{c}$, F. Botrè ${ }^{a, b}$

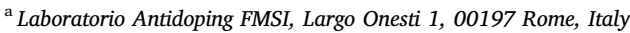 \\ b Department of Experimental Medicine, "Sapienza" University of Rome, Viale Regina Elena, 291, 00161 Roma, Italy \\ ${ }^{\mathrm{c}}$ Freie Universität Berlin, Institute of Pharmacy, Königin-Luise-Str. 2+4, 14195 Berlin, Germany
}

\section{A R T I C L E I N F O}

\section{Keywords:}

Formestane

Metabolism

Antidoping

Mass spectrometry

Route of administration

\begin{abstract}
A B S T R A C T
Formestane (4-hydroxyandrost-4-ene-3,17-dione, 4OH-AED) is an aromatase inhibitor prohibited in sports. In recent years, it has been demonstrated that it can also originate endogenously by the hydroxylation in C4 position of androstenedione. Thus, the use of isotope ratio mass spectrometry (IRMS) is mandatory according to the World Antidoping Agency (WADA) to discriminate endogenous from synthetic origin.

In a previous work and after oral administrations of formestane (4OH-AED), the ratio between the main formestane metabolite ( $4 \alpha$-hydroxyepiandrosterone; 4OH-EA) and formestane parent compound could help to identify the endogenous origin, avoiding unnecessary and costly IRMS confirmations. In the present work, we investigated whether the same criteria could also be applied after transdermal applications. Six volunteers were transdermally treated once with formestane. Urine samples were collected for $120 \mathrm{~h}$ postadministration and analyzed by gas chromatography coupled to mass spectrometry (GC-MS and GC-MS/MS). Formestane and its major metabolites were monitored.

The kinetic profile of formestane and its main metabolites was found different between oral and transdermal application. A shift on the excretion of the metabolites compared to formestane itself that can be observed after the oral administration, is absent after the transdermal one. This makes that a simple criteria cannot be applied to differentiate the endogenous from the synthetic origin based on metabolic ratios.

The ratio between 4-hydroxyepiandrosterone and 4-hydroxyandrosterone (4OH-A) can be used to differentiate the route of administration. Ratios higher than one $(4 \mathrm{OH}-\mathrm{EA} / 4 \mathrm{OH}-\mathrm{A}>1)$ are diagnostic of an oral administration. This allows to correctly interpret the 4OH-EA/4OH-AED ratio as proposed in our previous investigation. The results of this work demonstrate that the use of appropriate biomarkers (metabolic ratios) helps to reach correct conclusions without using complex and costly instrumentation approaches.
\end{abstract}

\section{Introduction}

Formestane (4-hydroxyandrost-4-ene-3,17-dione, 4OH-AED) is an anti-estrogenic drug used in the treatment of breast cancer. It is a type I aromatase inhibitor acting as a "suicide substrate". In women it suppresses estrogen formation and may be used therapeutically in those pathologies that are estrogen dependent (i.e. breast cancer) [1,2]. In humans, estrogens are strong pituitary inhibitors of gonadotrophin releasing factors. The inhibition of the estrogen synthesis produces an increase of luteinizing hormone (LH). After formestane, net increase of testosterone production has been described $[3,4]$ although robust data are not available. In addition, the combined administration with testosterone and/or its precursors (i.e. androstenedione) may reduce the side effects linked to aromatization like gynecomastia. For these reasons, anti-estrogenic substances including aromatase inhibitors are included since 2004 in the World Anti Doping Agency (WADA) List of Prohibited Substances in Sports in the section S4.1. "Hormones and metabolic modulators" [5].

The basic analytical methodologies developed so far are based on GC-MS(/MS) or LC-MS(/MS), targeting formestane itself. It has been demonstrated that traces of formestane may also be produced endogenously and found in urine samples in concentrations as low as $0.5-20 \mathrm{ng} / \mathrm{mL}$. Thus, since 2011 , it is mandatory according to the WADA rules to perform a confirmation based on isotope ratio mass spectrometry (GC/C/IRMS) in order to assess the synthetic origin of formestane for samples between 50 and $150 \mathrm{ng} / \mathrm{mL}$ before releasing an adverse analytical finding [6].

The urinary excretion of formestane and metabolism in the context

\footnotetext{
* Corresponding author at: Laboratorio Antidoping FMSI, Largo Giulio Onesti, 1, 00197 Rome, RM, Italy.

E-mail address: xavier.delatorre@fmsi.it (X. de la Torre).
} 


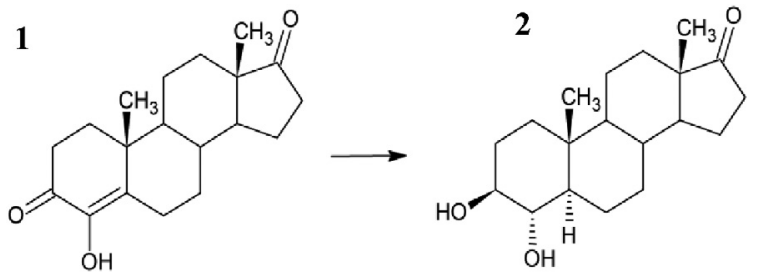

Fig. 1. Chemical structure of formestane [1] (4-hydroxyandrost-4-ene-3,17-

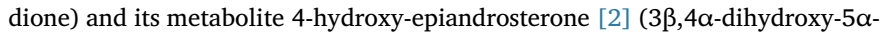
androstan-17-one).

of antidoping analyses has been described by Kohler et al. in a single male volunteer [7]. It appears that among the high number of metabolites described, $3 \beta, 4 \alpha$-dihydroxy-5 $\alpha$-androstan-17-one ( $4 \alpha$-hydroxyepiandrosterone; 4OH-EA) (Fig. 1) has the longest detection window, and this fact was confirmed latter by de la Torre et al. [8]. We demonstrated that after an oral dose of formestane the concentration of 4OH-EA is 2-10 times higher than formestane itself while in the cases of endogenous production found in real samples for doping control $(\mathrm{n}=10)$, the concentration of $4 \mathrm{OH}-\mathrm{EA}$ was not detected or detected below $2 \mathrm{ng} / \mathrm{mL}$. We also proposed to monitor 4OH-EA (and its ratio to formestane) in routine screening analysis as a diagnostic biomarker to identify the samples that deserve to be confirmed by IRMS.

Being a testosterone related chemical structure, it is expected that the metabolism of formestane follows the same route than testosterone and its derivatives. The phase I and II metabolism is supposed to yield oxidized, reduced and hydroxylated metabolites, as well as conjugated metabolites. Table 1 shows some structures described as potential urinary metabolites after the oral administration of formestane [7].

In the last years, the intramuscular route of administration of formestane (Lentanon ${ }^{\circledR}$ ) was withdrawn from the European market and was not approved by the FDA in the United States, due to the adverse reactions that could be related to the parenteral use of formestane (headache, rash, drowsiness, muscle cramps, fluid retention, oedema, dizziness, nausea and vomiting, abnormal vaginal bleeding, hot flushes, pain at the injection site, alopecia, pruritis, excessive hair growth on the face) [9] and was subsequently superseded by third-generation inhibitors such as letrozole. Besides, the oral route shows a very low bioavailability (around 4\%) and additionally, the substance is available on black market mainly as topical gel form. Taking into account these information it seems reasonable to dedicate time to study formestane metabolism administrated transdermally since it appears to be the administration route most probably use by athletes.

Human skin has a multifaceted role as the organ with the greatest direct exposure to the external environment. The epidermis is marked by the presence of resident dendritic cells, which are known as Langerhans cells (LC) that have the ability to transport drug-protein conjugates formed in situ from the skin to the lymphatic organs that are essential to mediate a systemic response.

The presence of the CYP1A enzymes in skin has been described by several investigators. Early studies demonstrated the capacity of animal skin to metabolize drugs that suggest the expression of CYP1A1, CYP1A2 and CYP1B1 in the skin $[10,11]$. Others researches have been studying the presence of CYP2A6 and CYP2B6 in skin biopsy samples. Members of the important CYP3A family of enzymes have also been detected in human skin cells [10-14].

Dehydroepiandrosterone (DHEA) and androstenedione, and possibly DHEA sulphate (DHEA-S), can be converted by skin cells into more potent androgens such as testosterone and dihydrotestosterone (DHT). Five main enzymes are involved in the activation and deactivation of androgens in the skin. In a first step, the steroid sulfatase hydrolyzes DHEA-S to DHEA. Subsequently, 3 3 -hydroxysteroid dehydrogenase- $\Delta^{5-}$ ${ }^{4}$-isomerase (3ß-HSD) converts DHEA to androstenedione. In an additional step, androstenedione is activated by conversion to testosterone through androgenic $17 \beta$-hydroxysteroid dehydrogenase (17 $\beta$-HSD). $5 \alpha$ Reductase irreversibly converts testosterone to DHT. Two isoforms of $5 \alpha$-reductase have been described so far. Type 1 dominates the skin, while type 2 predominates in the hair follicles of the beard. Finally, two isozymes of $3 \beta$-hydroxysteroid dehydrogenase may inactivate androgens to compounds that do not recognize the androgen receptor. The kidneys mainly eliminate the metabolites either by glucuronidation or by sulfation $[15,16]$.

A number of important transferases have also been observed in skin biopsy samples or cultured skin cells. In particular, analysis of skin biopsies has revealed the presence of mRNA for members of the glutathione S-transferases $[2,17]$ and sulfotransferases (SULT1A1, 1A3, 1E1, 2B1) $[2,15,16]$.

Sulfation of the hydroxy group on C3 or C17 moieties of steroid hormones as DHEA can be mediated by several of the SULT isozymes in both of the major gene families. SULT2A1 and SULT1E1 are considered to be two of the principal genes involved in this process [15]. Although sulfotransferases are also present in the skin and are important in drug metabolism and for some doping agents, the urinary sulphate fraction is not currently widespread used in the initial testing procedures by Antidoping laboratories and will not be the focus of the present work.

The goals of the present paper is to describe the differences in the metabolism of formestane when administrated by oral and transdermal routes. At the same time, it was intended to look for the best biomarkers of formestane administration in order to verify if the previous proposed criterion (4OH-EA/4OH-AED) based on oral administrations to select which samples be worthy to be confirmed by GC/C/IRMS in antidoping analysis is still valid after a transdermal administration.

Table 1

Proposed metabolites to be observed after formestane administration by Kohler et al. [7]

\begin{tabular}{|c|c|c|}
\hline Chemical structure & Synonym & $\mathrm{MW}(\mathrm{m} / \mathrm{z}$ as $-\mathrm{TMS})$ \\
\hline 4-hydroxy-androst-4-ene-3,17-dione & 4OH-androstenedione, $4 \mathrm{OH}$-AED, Formestane & 518 \\
\hline $3 \beta, 4 \alpha$-dihydroxy- $5 \alpha$-androstan-17-one & 4OH-epiandrosterone, 4OH-EA & 522 \\
\hline $3 \alpha, 4 \alpha$-dihydroxy- $5 \alpha$-androstan-17-one & 4OH-androsterone, $4 \mathrm{OH}-\mathrm{A}$ & 522 \\
\hline 4,17-dihydroxy-androst-4-ene-ol-3-one & 4OH-testosterone, $4 \mathrm{OH}-\mathrm{T}$ & 520 \\
\hline $3 \alpha, 4 \alpha$-dihydroxy-5 $\beta$-androstan-17-one & 4OH-etiocholanolone, $4 \mathrm{OH}-\mathrm{E}$ & 522 \\
\hline $3 \beta, 4 \alpha$-dihydroxy- $5 \beta$-androstan-17-one & 4OH-epietiocholanolone, 4OH-EE & 522 \\
\hline $3 \beta, 4 \beta$-dihydroxy-5 $\alpha$-androstan-17-one & & 522 \\
\hline $3 \alpha, 4 \beta$-dihydroxy- $5 \alpha$-androstan-17-one & $4 \beta$-OH-androsterone, $4 \beta$-OH-A & 522 \\
\hline $3 \alpha, 17 \beta$-dihydroxy-5 $\beta$-androstan-4-one & & 522 \\
\hline $3 \beta, 17 \beta$-dihydroxy-5 $\alpha$-androstan-4-one & & 522 \\
\hline 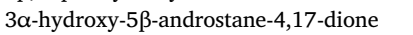 & & 520 \\
\hline 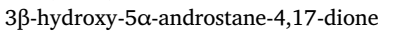 & & 520 \\
\hline 4-hydroxyandrosta-1,4-diene-3,17-dione & & 516 \\
\hline
\end{tabular}


Table 2

GC-MS(/MS) method characteristics. Retention times, selected ions or transitions and collision energy (CE) applied in the MS and MS/MS experiments.

\begin{tabular}{|c|c|c|c|c|c|}
\hline \multirow[t]{2}{*}{ Analyte } & \multicolumn{2}{|l|}{ GC/MS } & \multicolumn{3}{|c|}{ GC-MS/MS } \\
\hline & RT (min) & $\begin{array}{l}\text { SIM } \\
\text { selected } \\
\text { ions }(\mathrm{m} / \mathrm{z})\end{array}$ & RT (min) & $\begin{array}{l}\text { MRM } \\
\text { transitions } \\
(\mathrm{m} / \mathrm{z})\end{array}$ & CE (V) \\
\hline \multirow[t]{2}{*}{ MT (ISTD) } & \multirow[t]{2}{*}{13.5} & 446 & \multirow[t]{2}{*}{15.3} & $446>301$ & 5 \\
\hline & & 301 & & $301>169$ & 20 \\
\hline \multirow[t]{3}{*}{ 4OH-EA } & \multirow[t]{3}{*}{17.6} & 391 & \multirow[t]{3}{*}{16.1} & $393>213$ & 10 \\
\hline & & 393 & & $391>211$ & 10 \\
\hline & & 522 & & $522>507$ & 10 \\
\hline \multirow[t]{3}{*}{ 4OH-A } & \multirow[t]{3}{*}{12.5} & 522 & \multirow[t]{3}{*}{12.5} & $522>417$ & 5 \\
\hline & & 393 & & $522>393$ & 10 \\
\hline & & 507 & & $522>391$ & 10 \\
\hline \multirow{3}{*}{$\begin{array}{l}\text { 4OH-AED, } \\
\text { Formestane }\end{array}$} & \multirow[t]{3}{*}{16.1} & 518 & \multirow[t]{3}{*}{15.9} & $518>333$ & 30 \\
\hline & & 503 & & $518>385$ & 30 \\
\hline & & & & $503>321$ & 20 \\
\hline
\end{tabular}

\section{Experimental}

\subsection{Reference materials}

The standard of 4-hydroxyandrost-4-ene-3,17-dione (formestane; 4OH-AED) and $17 \alpha$-methyltestosterone (MT) were from Sigma-Aldrich (Milan, Italy) and 4-hydroxyandrost-4-ene-17ß-ol-3-one (4-hydroxytestosterone, 4OH-T) was from (NMIA, Pymble, Australia). $3 \beta, 4 \alpha-$

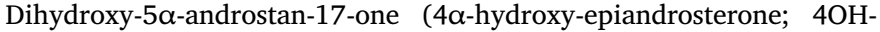
EA), $3 \alpha, 4 \alpha$-dihydroxy-5 $\alpha$-androstan-17-one ( $4 \alpha$-hydroxy-androsterone; 4OH-A), $3 \alpha$-hydroxy-5 $\beta$-androstan-4,17-dione, $3 \alpha, 17 \beta$-dihydroxy-5 $\beta$ androstan-4-one, $3 \alpha, 4 \beta$-dihydroxy- $5 \alpha$-androstan-17-one, 4-hydroxyandrost-1,4-diene-3,17-dione (1,2-dehydro-formestane; 1,2-DHF), 3ßhydroxy-5 $\alpha$-androstan-4,17-dione, were synthesized by Prof. MK. Parr group as previously described [18].

All reagents and solvents (sodium bicarbonate, potassium carbonate, sodium phosphate, sodium hydrogen phosphate, tert-butylmethyl ether) were of analytical or HPLC grade and provided by Carlo Erba (Milan, Italy). $\beta$-glucuronidase from Escherichia coli K12 was from Roche Diagnostic (Mannheim, Germany). Water was from a Milli-Q water purification system (Millipore S.p.A, Milan, Italy).

\subsection{Urine samples}

\subsubsection{Oral administration}

Three healthy male volunteers $(38.6 \pm 7$ years old, weighting $82.0 \pm 5 \mathrm{~kg}$ and normal body mass index) were administered orally (after informed consent approval) with a single capsule of the prohormone dietary supplement Formastat $^{\circledR}$ (Molecular Nutrition, Cambridge, MA, USA) claiming to contain $50 \mathrm{mg}$ of 4-hydroxyandrost4-ene-3,17-dione (Formestane). Before the administration, the composition of the capsule was examined. By using the instrumental conditions described in the next section, the presence of formestane could be confirmed and the occurrence of other substances in the formulation could be excluded. Blank urine samples were collected before administration and spot samples were collected for the next three days. Samples were stored at $-20^{\circ} \mathrm{C}$ until analysis.

\subsubsection{Transdermal administration}

Six healthy male volunteers $(25.6 \pm 6$ years old, weighting $69.4 \pm 18 \mathrm{~kg}$ and normal body mass index) were administered topically (after informed consent approval) with a single application of the cream Farmasurge ${ }^{\circledR}$ (Body Performance Solution, LLC, WA, USA) claiming to contain $200 \mathrm{mg}$ of 4-hydroxyandrost-4-ene-3,17-dione (Formestane). Blank urine samples were collected before administration and spot samples were collected for the next five days. Samples were stored at $-20^{\circ} \mathrm{C}$ until analysis.
The study with the human volunteers was approved by the Clinical Research Ethics Committee (CEIC-Parc de Salut MAR), Barcelona, Spain (2015/6249).

None of the volunteers participated in both studies.

\subsection{Sample preparation}

To $2 \mathrm{~mL}$ of urine $750 \mu \mathrm{L}$ of phosphate buffer $(0.8 \mathrm{M}, \mathrm{pH} 7), 50 \mu \mathrm{L}$ of $\beta$-glucuronidase from E. coli and $50 \mu \mathrm{L}$ of ISTD ( $17 \alpha$-methyltestosterone) were added. The samples were incubated for $1 \mathrm{~h}$ at $55^{\circ} \mathrm{C}$. After hydrolysis, $0.5 \mathrm{~mL}$ of carbonate/bicarbonate buffer $(20 \% \mathrm{w} / \mathrm{w})$, was added and liquid-liquid extraction was carried out with $5 \mathrm{~mL}$ of $t$-butylmethyl ether. The evaporated residue was derivatized at $70^{\circ} \mathrm{C}$ for $30 \mathrm{~min}$ to form the trimethylsilyl (TMS) derivatives.

\subsection{GC-MS/MS conditions for formestane screening}

For the mass spectrometric screening analysis, the chromatography was performed in a HP1MS (Agilent J\&W, CPS Analitica, Milano, Italy) methyl fused-silica capillary column $(17 \mathrm{~m} \times 0.2 \mathrm{~mm}$ i.d., $0.11 \mu \mathrm{m}$ film thickness). The initial temperature $188^{\circ} \mathrm{C}$ for $2.5 \mathrm{~min}$, was increased at $3{ }^{\circ} \mathrm{C} / \mathrm{min}$ to $211^{\circ} \mathrm{C}$ maintained $2 \mathrm{~min}$, increased at $10^{\circ} \mathrm{C} / \mathrm{min}$ to $238^{\circ} \mathrm{C}$ then at $40^{\circ} \mathrm{C} / \mathrm{min}$ to $320^{\circ} \mathrm{C}$ and kept $3.2 \mathrm{~min}$ at the final temperature. Helium was used as carrier gas at $0.8 \mathrm{~mL} / \mathrm{min}$ and injection, $2 \mu \mathrm{L}$ of extract, was performed in split (1:20) mode. The analyses were carried out on an Agilent 7890A gas chromatograph coupled to an Agilent 7000 triple quadrupole mass spectrometer (Agilent Technologies SpA, Cernusco sul Naviglio, Milan, Italy). Both the injector and transfer line operated at $280^{\circ} \mathrm{C}$. The data acquisition was performed in multiple reaction monitoring (MRM) (Table 2). This method was used for the determination of the steroid profile as defined in the WADA technical document TD2016EAAS used routinely by the laboratory. The steroid profile included quantitation of testosterone (T), epitestosterone (E),

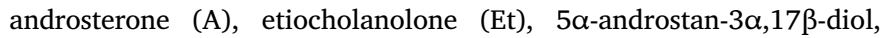
( $5 \alpha 3 \alpha), 5 \beta$-androstan-3 $3,17 \beta$-diol $(5 \beta, 3 \alpha)$ and the ratios T/E, A/Et, A/ T, $5 \alpha 3 \alpha / 5 \beta, 3 \alpha$ and $5 \alpha 3 \alpha / \mathrm{E}$.

\subsection{GC-MS conditions to study formestane metabolism}

To study the metabolism of formestane and to achieve a good resolution between $2 \xi$-hydroxy-androstenedione and 4-hydroxy-androstenedione (formestane) an HP5MS (5\%-Phenyl)-methylpolysiloxane fused-silica capillary column $(30 \mathrm{~m} \times 0.25 \mathrm{~mm}$ i.d., $0.20 \mu \mathrm{m}$ film thickness, Agilent J\&W, CPS Analitica, Milano, Italy) was used. The initial temperature was $185^{\circ} \mathrm{C}$ for $0.5 \mathrm{~min}$, increased at $40^{\circ} \mathrm{C} / \mathrm{min}$ to $235^{\circ} \mathrm{C}$, then increased at $0.05^{\circ} \mathrm{C} / \mathrm{min}$ to $236^{\circ} \mathrm{C}$ then at $50{ }^{\circ} \mathrm{C} / \mathrm{min}$ to $310^{\circ} \mathrm{C}$ and kept $10 \mathrm{~min}$ at the final temperature. Helium was used as carrier gas at $0.8 \mathrm{~mL} / \mathrm{min}$ and injection, $2 \mu \mathrm{L}$ of extract, was performed in split (1:10) mode. The analyses were carried out on an Agilent 6890A gas chromatograph coupled to an Agilent 5973 single quadrupole mass spectrometer (Agilent Technologies, Milan, Italy). Both the injector and transfer line operated at $280^{\circ} \mathrm{C}$. The data acquisition was performed in SCAN mode in order to look for the specific metabolites and then in SIM mode in order to improve the sensitivity. The principal characteristics of GC-MS-SIM and GC-QqQ-MRM analyses are show in Table 2.

All concentrations were corrected [19] by the specific gravity (SG) of the samples according to

$\mathrm{C}_{\text {corr }}=\mathrm{C}_{\text {measured }} *(1.020-1) /(\mathrm{SG}-1)$

\subsection{Validation of 4OH-AED, 4OH-EA and 4OH-A analysis}

Selectivity, precision, limit of detection (LOD), limit of quantitation (LOQ), linearity, and the identification capacity of the assay were evaluated.

Selectivity: The presence of $4 \mathrm{OH}-\mathrm{AED}$ and its metabolites $4 \mathrm{OH}-\mathrm{EA}$ 
and $4 \mathrm{OH}-\mathrm{A}$ was verified by routine observation in more than 100 urine samples. In addition, the samples collected before the administration of formestane were used. No interfering signals were detected in these samples.

Linearity was evaluated in a 5 levels calibration curve determined on 5 independent days. Linearity range was from 5 to $500 \mathrm{ng} / \mathrm{mL}$.

Precision (within and between assay) was evaluated by the analysis of spiked urine samples at $10 \mathrm{ng} / \mathrm{mL}$ during 6 independent days. The LOD and the LOQ were estimated respectively as $3 \times \mathrm{S}_{(y / x)} / \mathrm{b}$ and $10 \times S_{(y / x)} / b$, where $S_{(y / x)}$ is the standard error of the curve and $b$ the slope of the calibration curve.

\section{Results}

\subsection{Validation of the assay to evaluate urinary formestane by GC-MS}

The detection of formestane by GC-MS using a single quadrupole is apparently an easy task and low detection limits can be reached, since the mass spectrum of the per-TMS derivative shows an intense peak at $\mathrm{m} / \mathrm{z} 518$ and low fragmentation is obtained. However, the elution time on the GC system, an instrument frequently used by the anti-doping community, overlaps with the elution time of several other hydroxylated androgen metabolites with the same molecular weight (i.e., $2 \xi$ -

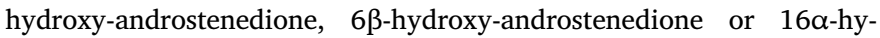
droxy-androstenedione) and other hydroxylated reduced metabolites that may compromise the selectivity of the method. This issue should be reviewed before its implementation in a routine method. The combination of chromatographic separation and/or mass spectrometric fragmentation, if tandem mass spectrometry is used, may produce the necessary selectivity. Table 3 describes the results of the assay validation for the analytes of interest in the study. Precision, limit of detection (LOD), limit of quantitation (LOQ) and linearity of the assay were evaluated as adequate for the purpose of the analysis: The identification capacity of the method fulfilled the WADA requirements [20].

No blank samples collected before the oral $(n=3)$ and transdermal $(n=6)$ applications in the excretion studies showed the presence of $4 \mathrm{OH}-\mathrm{EA}$ or $4 \mathrm{OH}-\mathrm{A}$, as well as the 100 urine samples from routine observation. Only three individuals showed formestane concentrations between the LOD and $20 \mathrm{ng} / \mathrm{mL}$, representing only the $2,7 \%$ of the samples.

\subsection{Effect of formestane administration on the steroid profile}

Since the initial evaluation of the formestane detection was performed using the same GC-MS/MS instrumental method used for establishing the steroid profile parameters of the Athletes' Biological Passport (ABP) according to WADA regulations [21], it was interesting to evaluate the physiological effect of the administration on these parameters. The individual alterations of the physiological excretion of such parameters is used to suspect indirectly of the abuse of testosterone or its precursors (i.e. androstenedione or DHEA). Considering the variation (mean \pm SD of the RSD \%) of the more diagnostic ratios T/E $(9 \pm 2), A / E t(11 \pm 6), 3 a 5 a / 3 a 5 b(14 \pm 9), A / T(20 \pm 5)$ and

Table 3

Validation results summary.

\begin{tabular}{llllll}
\hline Compound & $\begin{array}{l}\text { Within assay } \\
\text { precision } \\
\text { (CV\%) }\end{array}$ & $\begin{array}{l}\text { Between assay } \\
\text { precision } \\
\text { (CV\%) }\end{array}$ & $\begin{array}{l}\text { LOD } \\
(\mathrm{ng} / \mathrm{mL})\end{array}$ & $\begin{array}{l}\text { LOQ } \\
(\mathrm{ng} / \mathrm{mL})\end{array}$ & $\begin{array}{l}\text { Linearity } \\
\left(R^{2}\right)\end{array}$ \\
\hline Formestane & $\begin{array}{l}\text { Min.: } 0.3 \% \\
\text { Max.: } 3.8 \%\end{array}$ & $13.8 \%$ & 0.3 & 1.8 & $\begin{array}{l}\text { Min.: } 0.9931 \\
\text { Max.: } 0.9984\end{array}$ \\
4OH-EA & $\begin{array}{l}\text { Min.: } 0.7 \% \\
\text { Max.: } 19.6 \%\end{array}$ & $20.0 \%$ & 1.0 & 5.0 & $\begin{array}{l}\text { Min.: } 0.9940 \\
\text { 4OH-A }\end{array}$ \\
$\begin{array}{l}\text { Min.: } 0.5 \% \\
\text { Max.: } 10.2 \%\end{array}$ & $15.4 \%$ & 0.5 & 2.5 & $\begin{array}{l}\text { Min.: } 0.99938 \\
\text { Max.: } 0.9988\end{array}$ \\
\hline
\end{tabular}

3a5a/E $(12 \pm 2)$, these showed an overall variation below $20 \%$ after the transdermal application. Such variation is considered as physiological and even using the current adaptive model based on Bayesian statistics [22] (a more sensitive approach) would not give different conclusions.

After the oral application, although the exposition to formestane was higher, the observed variations were nor significantly different (T/ $\mathrm{E}(14 \pm 2), \mathrm{A} / \mathrm{Et}(10 \pm 2), 3 \mathrm{a} 5 \mathrm{a} / 3 \mathrm{a} 5 \mathrm{~b}(12 \pm 3), \mathrm{A} / \mathrm{T}(16 \pm 3)$ and $3 \mathrm{a} 5 \mathrm{a} / \mathrm{E}(14 \pm 8))$. Most probably repeated applications are needed to evidence any effect on these markers.

\subsection{Metabolism of formestane after transdermal and oral administration- qualitative overview}

In antidoping analyses the use of pure $\beta$-glucuronidase enzymatic preparations is preferred for the hydrolysis of glucuronoconjugated steroids. This is not only since this is regulated by WADA through its technical documents for the establishment of the urinary steroid profile, but also because mixed glucuronidase/sulfatase preparations, often present non desired side reactions [21]. Besides, the information obtained regarding steroids metabolism is wider and easier to be compared with the available literature. The authors do not discard that the analysis of the urinary sulphate fraction may show additional information on the differences between the two administration routes studied but is not the scope of the present manuscript.

In the two different experiments carried out using two different administration routes only the free plus glucuronoconjugated metabolites were considered. Samples obtained from two urinary excretion studies (transdermal, $n=6$ and oral, $n=3$ ) were analyzed by GC-MS with the aim of investigating in depth the metabolism of formestane. This should allow selecting the best biomarkers for detecting its abuse in sports, besides 4OH-EA, as already described by de la Torre et al. [8] after oral administrations. In addition, it would be possible to search for some parameter that may allow to discriminate between oral and transdermal administration route if this may have any future interest.

The qualitative analyses of the urinary extracts by GC-MS in full scan mode permitted the detection of several formestane metabolites already described by Kohler et al. [7] presented in Table 1. The identification was assigned based on the comparison of the retention times and mass spectra with reference materials. The main metabolites detected in both administrations routes are described in Table 4 and Figs. 2 and 3, confirming differences between the metabolism and enzymatic systems present in both gastrointestinal tract and skin absorptions.

As expected, the metabolites with $3 \alpha$-configuration predominate in both administration routes (because as already indicated, only the hydrolysis of glucuronated plus free compounds was considered), with the exception of 4OH-EA, which was observed as the second major metabolite (after $4 \mathrm{OH}-\mathrm{A}$ ). $5 \alpha$-and $5 \beta$-configurations were observed in both administration routes. The $5 \alpha$-configuration showed $4 \alpha / 4 \beta$-hydroxy, -17-oxo metabolites while the $5 \beta$-configuration showed 4 -oxo- $17 \beta$ -

\section{Table 4}

Summary of the metabolites detected after administration of a single dose of transdermal and oral formestane. (Y: yes, N: no).

\begin{tabular}{|c|c|c|c|}
\hline ID & Structure & Transdermal & Oral \\
\hline 4OH-AED & 4-hydroxyandrost-4-ene-3,17-dione & $\mathrm{Y}$ & $\mathrm{Y}$ \\
\hline 4OH-EA & $3 \beta, 4 \alpha$-dihydroxy- $5 \alpha$-androstan-17-one & $\mathrm{Y}$ & $\mathrm{Y}$ \\
\hline $4 \mathrm{OH}-\mathrm{T}$ & 4,17-dhydroxy-androst-4-ene-3-one & $\mathrm{Y}$ & $\mathrm{Y}$ \\
\hline- & $3 \alpha$-hydroxy- $5 \beta$-androstan-4,17-dione & $\mathrm{Y}$ & $\mathrm{Y}$ \\
\hline- & $3 \alpha, 17 \beta$-dihydroxy- $5 \beta$-androstan-4-one & $\mathrm{Y}$ & $\mathrm{Y}$ \\
\hline $4 \beta-\mathrm{OH}-\mathrm{A}$ & $3 \alpha, 4 \beta$-dihydroxy- $\alpha \alpha$-androstan-17-one & $\mathrm{Y}$ & $\mathrm{Y}$ \\
\hline $4 \mathrm{OH}-\mathrm{A}$ & $3 \alpha, 4 \alpha$-dihydroxy- $5 \alpha$-androstan-17-one & $\mathrm{Y}$ & $\mathrm{Y}$ \\
\hline 1,2-DHF & 4-hydroxyandrosts-1,4-diene-3,17-dione & $\mathrm{N}$ & $\mathrm{Y}$ \\
\hline- & $3 \beta$-hydroxy- $5 \alpha$-androstane-4,17-dione & $\mathrm{N}$ & $\mathrm{Y}$ \\
\hline
\end{tabular}



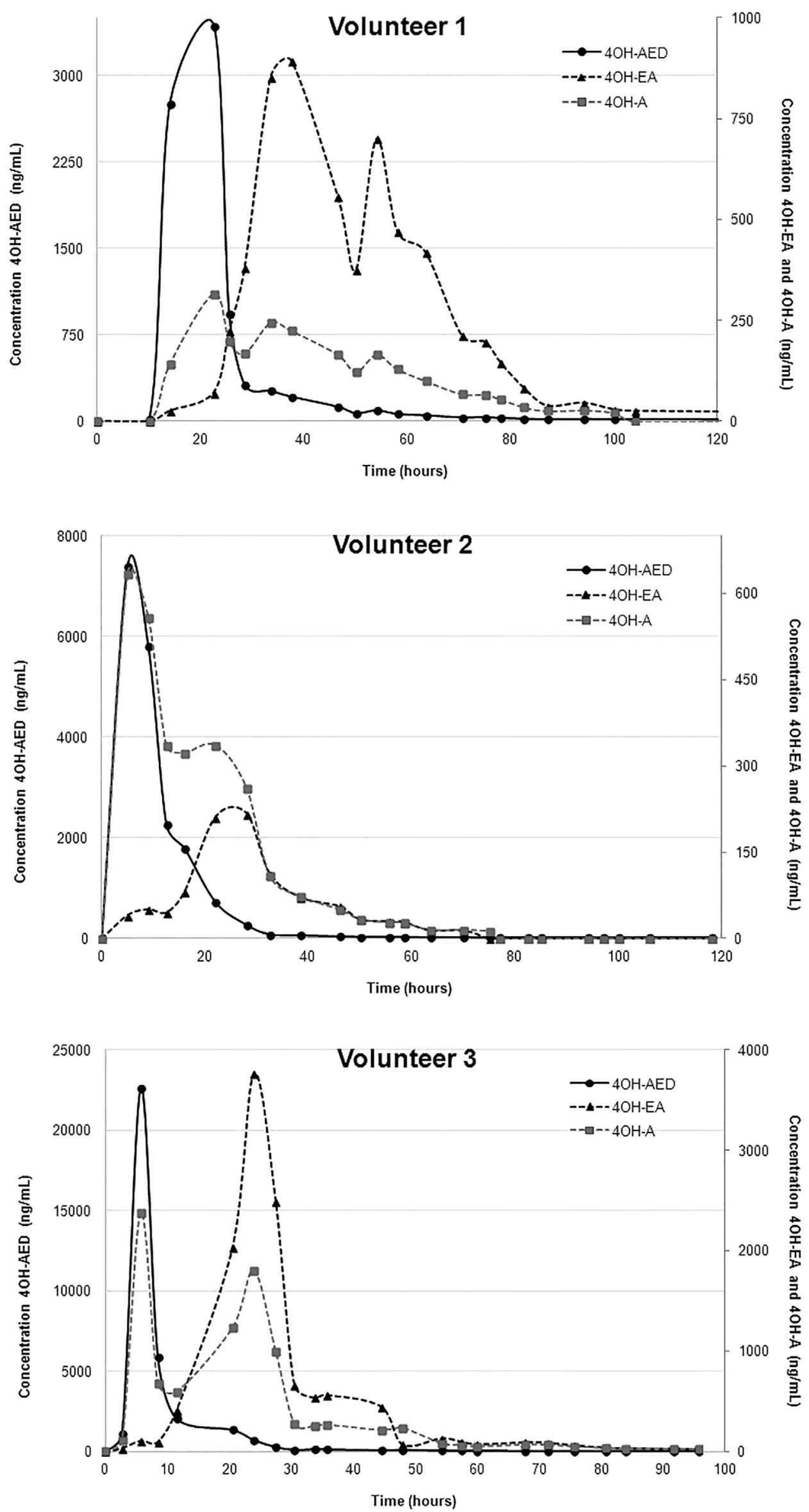

(caption on next page) 


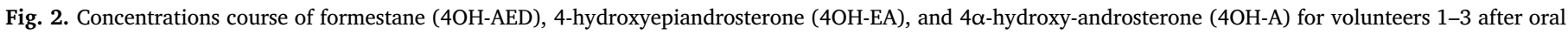
administration.

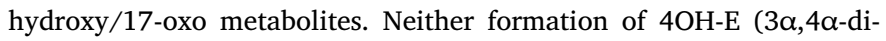
hydroxy-5 $\beta$-androstan-17-one; $4 \alpha$-hydroxy-etiocholanolone) nor $4 \mathrm{OH}$ EE $(3 \beta, 4 \alpha$-dihydroxy- $5 \beta$-androstan-17-one; $4 \alpha$-hydroxy-epietiocholanolone) was observed on both routes of administration, indicating a potential interaction of the hydroxyl group in $\mathrm{C} 4$ with the $5 \beta$-reductase. This is in line with the previously reported findings of Kohler et al [7] in a single volunteer after an oral administration. The 17-oxo metabolites predominated in both administration routes, except for $3 \alpha, 17 \beta$-dihydroxy-5 $\beta$-androstan-4-one observed in the oral route and in 4 out of the
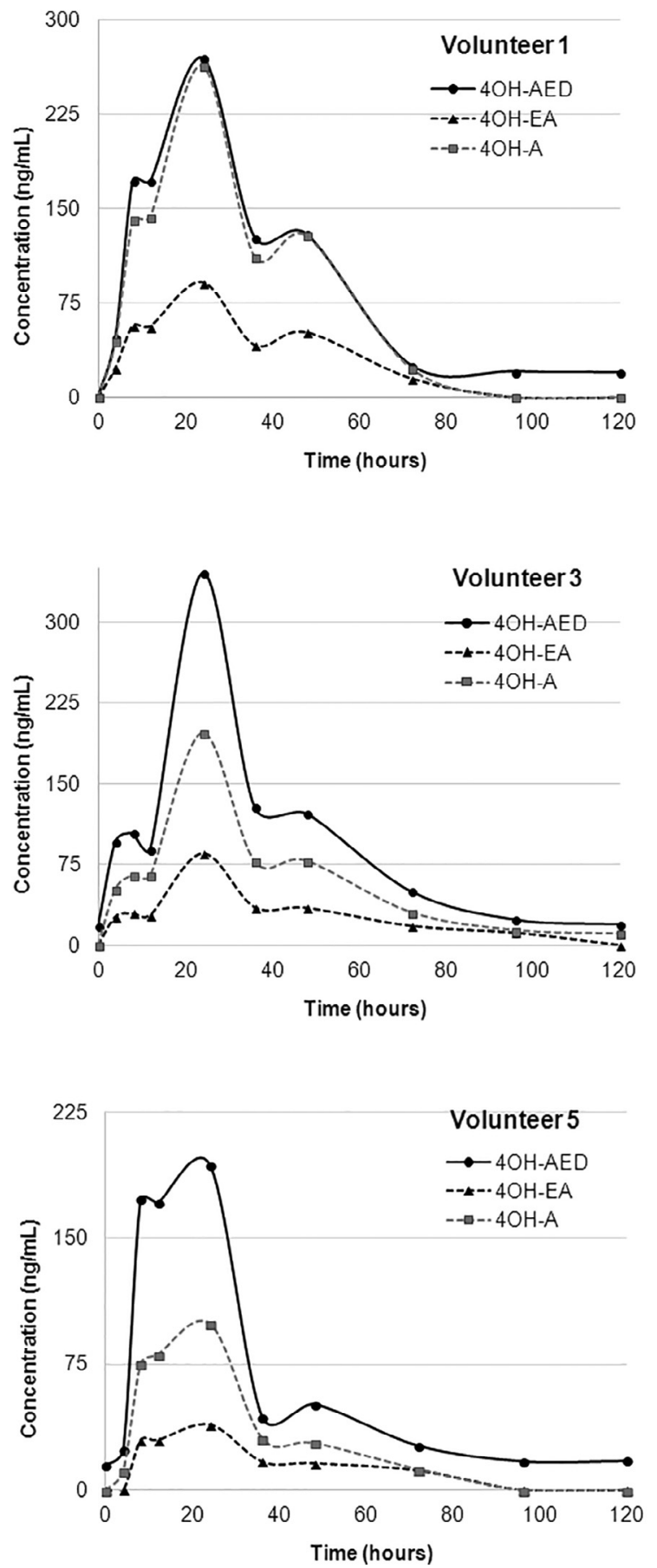

6 volunteers of transdermal administration ( $67 \%$ of volunteers). After the oral administration route the metabolite $3 \beta$-hydroxy- $5 \alpha$-androstane-4,17-dione and 1,2-DHF were observed, while they were undetectable after transdermal administration.

There are several factors that influence the metabolism in the skin like temperature, level of hydration or the additional elements of the formulation that improve the absorption of the applied drug, among others. The enzymatic system present in this organ is extensive, although some already known differences for steroids metabolism in
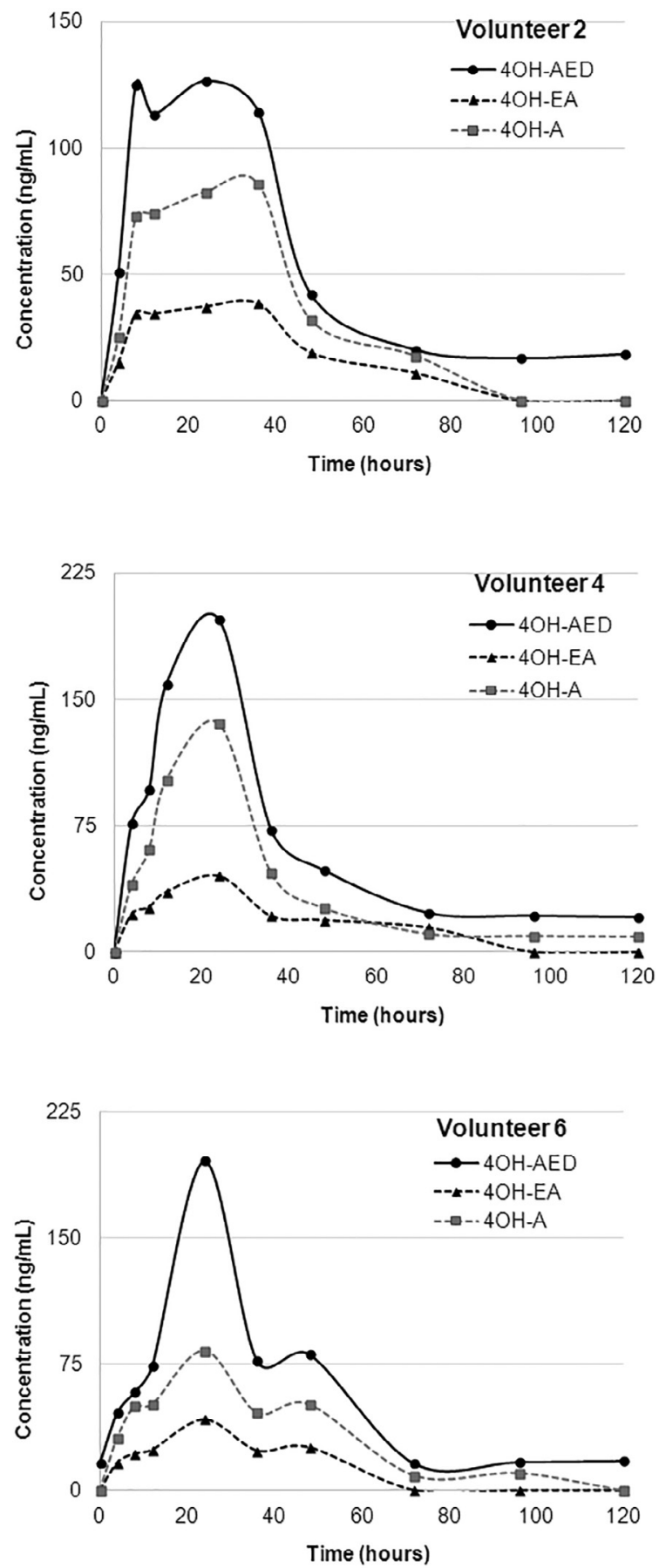

Fig. 3. Individual concentrations course observed after the transdermal route $(n=6)$.for formestane $(4 \mathrm{OH}$-AED), $4 \alpha$-hydroxy-epiandrosterone $(4 \mathrm{OH}$-EA) and $4 \alpha$ hydroxy-androsterone (4OH-A). 
transdermal applications compared with oral route have been described [23]. Once the parent drug/metabolites are absorbed through the skin, the hepatic metabolism cannot be discarded, as well as the formation of metabolites with estrogenic structure.

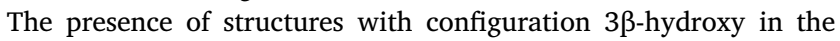
analyzed fraction of urine (glucuronide plus free fraction) may be probably a consequence of the simultaneous presence and reversible action of sulfotransferases and sulfatases enzymes in skin. Accordingly, it is possible to find urinary metabolites in the free form when it is supposed that most of them be present in sulphate form. Studies in skin metabolism demonstrated the abundance of sulfotransferases family over the glucuronyl-transferases. Out of them, the subfamily SULT2B1b is selective for the sulfation of $3 \beta$-hydroxysteroids also in skin $[15,16]$. Following this assumption, the most expected abundant metabolites could be with $3 \beta$-configuration in transdermal administration compared to the oral one.

Finally, the two metabolites found in oral administration that were not found in the transdermal one, did not respond to a similar structural configuration. Since both are very minor metabolites, we cannot exclude that this is produced by the different exposition to formestane reached by both administration routes, leading to concentrations below the detection limit of the instrument and/or assay applied.

\subsection{Concentration profiles-quantitative evaluation}

\subsubsection{Oral administration}

The concentrations are variable as well as the maximum time of excretion due to inter-individual variations $(n=3)$. No 4OH-AED, $4 \mathrm{OH}-\mathrm{EA}$ or $4 \mathrm{OH}-\mathrm{A}$ were detected in the pre-administration samples at the LODs of the method. The concentrations observed in decreasing intensity were 4OH-AED > 4OH-EA > 4OH-A (Table 5 and Fig. 2).

As can be noticed, $4 \mathrm{OH}-\mathrm{AED}$ showed a very rapid absorption with a $\mathrm{C}_{\max }$ at ca. 5-6h after oral administration and it was detectable for $60-75 \mathrm{~h}$ as parent compound, showing concentrations below $150 \mathrm{ng} /$ $\mathrm{mL}$ after ca. $30 \mathrm{~h}$. Formestane metabolite $4 \mathrm{OH}-\mathrm{EA}$, showed a delayed formation and excretion, presenting a urinary $\mathrm{C}_{\max }$ at $20-24 \mathrm{~h}$ and it was detectable for a longer time, until ca. 70-90 h. During the time interval when $4 \mathrm{OH}-\mathrm{AED}$ concentrations were between $50 \mathrm{ng} / \mathrm{mL}$ and $150 \mathrm{ng} / \mathrm{mL}$, the interval when the IRMS confirmation is mandatory in doping control, the concentrations of $4 \mathrm{OH}-\mathrm{EA}$ are 6-10 times higher. After oral administration, two additional metabolites were observed compared to the transdermal administration. The 4-hydroxy-androsta-

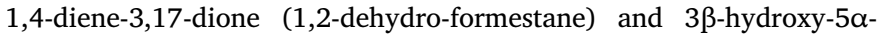
androstan-4,17-dione showed no significant concentrations that could bring more information than other metabolites (see Table 4).

Table 5

Maximum concentrations observed in the study of the metabolism of Formestane administered orally.

\begin{tabular}{|c|c|c|c|}
\hline \multirow[t]{2}{*}{ Analyte } & \multicolumn{3}{|c|}{$\mathrm{C}_{\max }(\mathrm{ng} / \mathrm{mL}) / \mathrm{t}_{\max }$ (hours) } \\
\hline & Individual 1 & Individual 2 & Individual 3 \\
\hline 4OH-AED & $3435 / 22$ & $7412 / 5$ & $11323 / 6$ \\
\hline 4OH-EA & $854 / 33$ & $217 / 28$ & $1884 / 24$ \\
\hline $4 \mathrm{OH}-\mathrm{A}$ & $316 / 22$ & $636 / 11$ & $1192 / 6$ \\
\hline $4 \beta-\mathrm{OH}-\mathrm{A}$ & $37 / 22$ & $427 / 9$ & $168 / 6$ \\
\hline $4 \mathrm{OH}-\mathrm{T}$ & $26 / 22$ & $59 / 16$ & $45 / 6$ \\
\hline 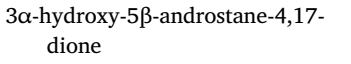 & $184 / 22$ & $339 / 9$ & $244 / 6$ \\
\hline $\begin{array}{l}3 \alpha, 17 \beta \text {-dihydroxy- } 5 \beta \text {-androstan- } 4 \text { - } \\
\text { one }\end{array}$ & $26 / 33$ & $27 / 17$ & $34 / 6$ \\
\hline $\begin{array}{l}\text { 4-hydroxy-androst-1,4-ene-3,17- } \\
\text { dione }\end{array}$ & $314 / 22$ & $61 / 5$ & $355 / 9$ \\
\hline $\begin{array}{l}\text { 3 } \beta \text {-hydroxy- } 5 \alpha \text {-androstane- } 4,17 \text { - } \\
\text { dione }\end{array}$ & $23 / 22$ & $10 / 13$ & $15 / 6$ \\
\hline
\end{tabular}

Table 6

Concentrations of main metabolites found in urine after Formestane transdermal administration.

\begin{tabular}{|c|c|c|}
\hline Analyte & $\begin{array}{l}\mathrm{C}_{\max } \\
(\mathrm{ng} / \mathrm{mL})\end{array}$ & $\begin{array}{l}t_{\max } \\
\text { (hours) }\end{array}$ \\
\hline 4OH-AED & $126-346$ & 24 \\
\hline 4OH-EA & $38-91$ & $24 *$ \\
\hline $4 \mathrm{OH}-\mathrm{A}$ & $86-264$ & $24 *$ \\
\hline $4 \beta-\mathrm{OH}-\mathrm{A}$ & $21-65$ & $24 *$ \\
\hline $4 \mathrm{OH}-\mathrm{T}$ & $8,3-11$ & $24 *$ \\
\hline $3 \alpha$-hydroxy-5 $\beta$-androstane-4,17-dione & $20-47$ & $24 *$ \\
\hline $3 \alpha, 17 \beta$-dihydroxy- $5 \beta$-androstan-4-one & $9-17,6$ & 24 \\
\hline
\end{tabular}

(*) Except volunteer 2 which $t_{\max }$ was at $36 \mathrm{~h}$.

\subsubsection{Transdermal administration}

Table 6 shows the time at which maximum concentrations $\left(t_{\max }\right)$ were observed during transdermal administration. Out of the 6 volunteers, 3 showed endogenous formestane (concentration in pre-administration samples from 15 to $18 \mathrm{ng} / \mathrm{mL}$ ) and at the end of the study the levels were similar to the initial ones (from 17 to $19 \mathrm{ng} / \mathrm{mL}$ ). For the rest of the volunteers, basal concentrations were below the LOD of the method or missing and, at the end of the study (120 h) the concentrations observed were between 18 and $21 \mathrm{ng} / \mathrm{mL}$. As it was described earlier, no $4 \mathrm{OH}-\mathrm{EA}$ or $4 \mathrm{OH}-\mathrm{A}$ were detected in blank samples collected before the transdermal administration of formestane.

After a single transdermal dose of $40 \mathrm{H}-\mathrm{AED}$, maximum concentrations were observed at $24 \mathrm{~h}$ and in decreasing order of concentrations were 4OH-AED $>40 \mathrm{H}-\mathrm{A}>4 \mathrm{OH}$-EA (Fig. 3). Although 4OH-T showed a slight increase at $24 \mathrm{~h}$, this was not relevant after the transdermal administration, suggesting that formestane administered by this route does not follow a similar known metabolism for androstenedione.

Metabolites $4 \mathrm{BOH}-\mathrm{A}$ and $4 \mathrm{OH}-\mathrm{EA}$ were completely eliminated after $120 \mathrm{~h}$, whereas $3 \alpha$-hydroxy-5 $\beta$-androstan-4,17-dione showed concentrations between 6 and $8 \mathrm{ng} / \mathrm{mL}$ (except for one volunteer). At the same time $(120 \mathrm{~h})$ the $4 \mathrm{OH}-\mathrm{A}$ showed concentrations close to $10 \mathrm{ng} / \mathrm{mL}$ in two cases.

The fact that under physiological conditions the body does not produce relevant amounts of $4 \mathrm{OH}-\mathrm{EA}$ and $4 \mathrm{OH}-\mathrm{A}$, may eliminate the need to perform the GC-C-IRMS assay to verify the exogenous or endogenous origin of formestane as requested by WADA technical document. Table 7 shows the concentrations of both metabolites in samples with concentrations of formestane between 50 and $150 \mathrm{ng} / \mathrm{mL}$ (IRMS criterion) for transdermal and oral studies. Both, oral and transdermal administration resulted in high levels of its major metabolites in those samples.

\subsubsection{Metabolic ratios}

The urinary concentration time-course depends on the individual metabolism and diuresis leading to high variations. In addition, in

\section{Table 7}

Concentrations of the metabolites $4 \alpha$-hydroxyepiandrosterone (4OH-EA) and $4 \alpha$-hydroxyandrosterone ( $4 \mathrm{OH}-\mathrm{A})$ in sample where the concentration of formestane was between 50 and $150 \mathrm{ng} / \mathrm{mL}$.

\begin{tabular}{|c|c|c|c|}
\hline & Metabolite ID & $\begin{array}{l}\text { Minimum } \\
\text { concentration } \\
(\mathrm{ng} / \mathrm{mL})\end{array}$ & $\begin{array}{l}\text { Maximum } \\
\text { concentration } \\
(\mathrm{ng} / \mathrm{mL})\end{array}$ \\
\hline \multirow[t]{2}{*}{ Oral $(\mathrm{n}=3)$} & 4OH-A & $\begin{array}{l}\text { Range } 100-70 \\
\text { Mean: } 84 \pm 15\end{array}$ & $\begin{array}{l}\text { Range } 278-110 \\
\text { mean: } 184 \pm 86\end{array}$ \\
\hline & 4OH-EA & $\begin{array}{l}\text { Range } 418-66 \\
\text { Mean: } 185 \pm 202\end{array}$ & $\begin{array}{l}\text { Range } 663-113 \\
\text { Mean: } 444 \pm 292\end{array}$ \\
\hline \multirow[t]{2}{*}{$\begin{array}{c}\text { Transdermal } \\
\qquad(\mathrm{n}=6)\end{array}$} & 4OH-A & $\begin{array}{l}\text { Range 112-25 } \\
\text { Mean: } 45 \pm 34\end{array}$ & $\begin{array}{l}\text { Range 263-83 } \\
\text { Mean: } 144 \pm 72\end{array}$ \\
\hline & 4OH-EA & $\begin{array}{l}\text { Range } 41-15 \\
\text { Mean: } 22 \pm 10\end{array}$ & $\begin{array}{l}\text { Range } 91-38 \\
\text { Mean: } 57 \pm 25\end{array}$ \\
\hline
\end{tabular}


Table 8

Summary of the proposed decision criteria to be applied for samples in the concentration range of $50-150 \mathrm{ng} / \mathrm{mL}$ of formestane.

\begin{tabular}{llcl}
\hline Administration route & \multicolumn{3}{l}{$50 \mathrm{ng} / \mathrm{mL}<[4$ OH-AED $]<150 \mathrm{ng} / \mathrm{mL}$} \\
\cline { 2 - 4 } & $\begin{array}{l}\text { 4OH-EA } \\
\text { 4OH-A }\end{array}$ & 4OH-EA $/ 4$ OH-AED & 4 OH-A/4OH-AED \\
& $>1$ & $>1(1.5-9)^{*}$ & $>1(1.2-4)^{*}$ \\
\hline $\begin{array}{c}\text { Oral }(30-60 \text { h post adm }) \\
(\mathrm{n}=3)\end{array}$ & $<1$ & $<1(0.2-0.3)^{*}$ & $<1(0.6-0.7)^{*}$ \\
$\begin{array}{c}\text { Transdermal }(4-60 \mathrm{~h} \\
\text { post adm })(\mathrm{n}=6)\end{array}$ & & &
\end{tabular}

* In parenthesis the interval of values observed in the sample of the volunteers participating to the study.

doping control only spot urine samples are collected, and for this reason, the use of metabolic ratios in the evaluation of urine samples is preferred. Taking into account the major metabolites in both formestane administration routes, $4 \mathrm{OH}-\mathrm{EA}$ and $4 \mathrm{OH}-\mathrm{A}$, and following the criterion by de la Torre et al [8] using ratios as biomarkers, a difference was found for both administration routes. Since the main metabolite in urine is not the same after oral or transdermal administration, the ratios to formestane were different. While after the oral administration the ratio $4 \mathrm{OH}-\mathrm{EA} / 4 \mathrm{OH}-\mathrm{AED}$ is always higher than $4 \mathrm{OH}-\mathrm{A} / 4 \mathrm{OH}-\mathrm{AED}$ ratio, in the transdermal route is exactly the opposite.

Table 8 shows the profile of the ratio of $4 \mathrm{OH}-\mathrm{EA}$ to $4 \mathrm{OH}-\mathrm{A}$ in both administration routes. The ratios show always values lower than 1 for transdermal and higher than 1 in oral administration when glucuronide plus free fractions were analyzed.

\subsubsection{Application in the antidoping field}

According to WADA TD2016IRMS, samples showing formestane in the $50-150 \mathrm{ng} / \mathrm{mL}$ range must be confirmed by IRMS before releasing and Adverse Analytical Finding. This range of concentrations is quite conservative since the available data in the literature [24-27] showed that the potential endogenous production is at a much lower range. In the four works cited, the maximum range of the population is at ca. $50 \mathrm{ng} / \mathrm{mL}$ or lower depending on the statistical data treatment. This is in agreement with the low concentration of formestane found in the blank samples of some of the volunteers participating in the study. When estimating the formestane concentration, one should be careful to avoid co-elution of isomeric compounds (i.e $2 \xi$-hydroxy-androstenedione) that may provoke an overestimation. The fact is that out of 35,000 samples analyzed in our laboratory less than 10 (confirmed as negatives after IRMS analyses) showed concentrations in the $50-150 \mathrm{ng} / \mathrm{mL}$ range $(0.03 \%)$.

In a previous work [8], we proposed the $4 \mathrm{OH}-\mathrm{EA} / 4 \mathrm{OH}-\mathrm{AED}$ ratio as a biomarker to disclose the endogenous production of formestane. The criteria is based on the delayed excretion of 4OH-EA (and also of $4 \mathrm{OH}-$ A) compared to $4 \mathrm{OH}$-AED itself, fitting the $50-150 \mathrm{ng} / \mathrm{mL}$ interval. This shift on the excretion is not anymore observed after transdermal applications where the $t_{\max }$ of $4 \mathrm{OH}-\mathrm{AED}, 4 \mathrm{OH}-\mathrm{EA}$ and $4 \mathrm{OH}-\mathrm{A}$ are almost identical. Thus single criteria cannot be applied to potentially identify the transdermal applications as well.

The use of the $4 \mathrm{OH}-\mathrm{EA} / 4 \mathrm{OH}-\mathrm{A}$ ratio as additional criterion, could be used to differentiate the administration route as indicated in Table 8. A ratio higher than 1 would support an oral administration and then the previously reported criteria could be applied. 4OH-A could also be applied but the $4 \mathrm{OH}-\mathrm{A} / 4 \mathrm{OH}-\mathrm{AED}$ ratio is less sensitive and $4 \mathrm{OH}-\mathrm{A}$ is more prone to present chromatographic interferences depending on the GC program used.

\section{Conclusions}

In the current study,a single quadrupole MS was used as detector and themost critical point was not related to the sensitivity to be reached, but to the selectivity of the compounds of interest. Being structures related to endogenous compounds and having similar or exactly the same molecular weight, the chromatographic separation demonstrated to produce an adequate selectivity. The obtained results demonstrate that for metabolic studies the method applied is completely satisfactory. In the Antidoping field, most of the analyses are performed in MS/MS and it is not obvious by using this detector that the problems encountered can be solved. This technique is certainly more sensitive but without appropriate chromatography may lack of the needed selectivity.

Formestane metabolism after oral and transdermal routes showed some differences. Taking as main references the previous studies by Kohler and de la Torre [7,8], 6 and 8 metabolites were detected in the free plus glucuronoconjugate urine fraction after transdermal and oral administration respectively. Out of these, 4-hydroxyandrost-1,4-ene3,17 -dione (1,2-dehydroformestane) and 3 3 -hydroxy-5 $\alpha$-androstane4,17-dione were observed only after oral administration.

The metabolites $4 \alpha$-hydroxy-androsterone (4OH-A) and $4 \alpha$-hydroxy-epiandrosterone (4OH-EA) were not observed in any urine sample collected before administration of formestane $(n=9)$ at the LOD's of the method, so its endogenous origin can most probably be ruled out. This makes them suitable markers for the detection of an exogenous administration of formestane avoiding the application of GCC-IRMS with the consequent reduction of the analysis costs. The concentrations achieved during both studies (transdermal and oral) are easily detectable by GC-MS techniques using SIM or MRM modes if the adequate transitions and chromatographic conditions are set up.

The behavior of the evaluated ratios showed that in transdermal administration, the $4 \mathrm{OH}-\mathrm{EA} / 4 \mathrm{OH}-\mathrm{AED}$ ratio is lower than the $4 \mathrm{OH}-\mathrm{A} /$ $4 \mathrm{OH}-\mathrm{AED}$ ratio for most of the samples analyzed. In contrast, in the oral administration a completely reversed behavior was observed. The $4 \mathrm{OH}-$ $\mathrm{EA} / 4 \mathrm{OH}-\mathrm{AED}$ ratio is higher than the other two ratios. The use of the 4OH-EA/4OH-A ratio may allow discriminate between a transdermal and oral administration of formestane. This would allow a better interpretation of the cases were formestane is detected.

\section{Acknowledgement}

The authors acknowledge the financial support of WADA (Grant 14A34XD).

\section{References}

[1] M. Dowsett, P.E. Goss, T.J. Powles, G. Hutchinson, A.M.H. Brodie, S.L. Jeffcoate, R.C. Coombes, Use of the aromatase inhibitor 4-hydroxyandrostenedione in postmenopausal breast cancer: optimization of therapeutic dose and route, Cancer Res. 47 (1987) 1957-1961.

[2] P.E. Lønning, J. Geisler, D.C. Johannessen, H.-P. Gschwind, F. Waldmeier, W. Schneider, B. Galli, T. Winkler, W. Blum, H.-P. Kriemler, W.R. Miller, J.W. Faigle, Pharmacokinetics and metabolism of formestane in breast cancer patients, J. Steroid Biochem. Mol. Biol. 77 (2001) 39-47.

[3] G.J. van Londen, S. Perera, K. Vujevich, P. Rastogi, B. Lembersky, A. Brufsky, V. Vogel, S.L. Greenspan, The impact of an aromatase inhibitor on body composition and gonadal hormone levels in women with breast cancer, Breast Cancer Res. Treat. 125 (2011) 441-446.

[4] D.S. Willoughby, C. Wilborn, L. Taylor, W. Campbell, Eight weeks of aromatase inhibition using the nutritional supplement Novedex XT: effects in young, eugonadal men, Int. J. Sport. Nutr. Exerc. Metab. 17 (2007) 92-108.

[5] WADA. The World Anti-Doping Code - The 2018 Prohibited List International Standard, Available at: https://www.wada-ama.org/sites/default/files/prohibited list_2018_en.pdf, 2018.

[6] WADA, TD2016 IRMS-Detection of synthetic forms of endogenous anabolic androgenic steroids by GC-C-IRMS, Available at: https://wada-main-prod.s3. amazonaws.com/resources/files/wada-td2016irms-detection_synthetic_forms_eaas_ by_irms-en.pdf, 2016.

[7] M. Kohler, M.K. Parr, G. Opfermann, M. Thevis, N. Schlörer, F.-J. Marner, W. Schänzer, Metabolism of 4-hydroxyandrostenedione and 4-hydroxytestosterone: Mass spectrometric identification of urinary metabolites, Steroids 72 (2007) $278-286$.

[8] X. de la Torre, C. Colamonici, D. Curcio, D. Jardines, F. Molaioni, M.K. Parr, F. Botrè, Detection of formestane abuse by mass spectrometric techniques, Drug Test. Anal. 6 (2014) 1133-1140. 
[9] D.S. Wishart, Y.D. Feunang, A.C. Guo, E.J. Lo, A. Marcu, J.R. Grant, T. Sajed, D. Johnson, C. Li, Z. Sayeeda, N. Assempour, I. Iynkkaran, Y. Liu, A. Maciejewski, N. Gale, A. Wilson, L. Chin, R. Cummings, D. Le, A. Pon, C. Knox, M. Wilson, DrugBank 5.0: a major update to the DrugBank database for 2018, Nucleic Acids Res. 46 (2018) D1074-D1082.

[10] C.K. Svensson, N.H. Shear, N. Zahid, Biotransformation of drugs in human skin, Drug Metab. Dispos. 37 (2009) 247-253.

[11] J.M. Baron, D. Höller, R. Schiffer, S. Frankenberg, M. Neis, H.F. Merk, F.K. Jugert, Expression of multiple cytochrome p450 enzymes and multidrug resistance-associated transport proteins in human skin keratinocytes, J. Invest. Dermatol. 116 (2001) 541-548.

[12] L.G. Yengi, Q. Xiang, J. Pan, J. Scatina, J. Kao, S.E. Ball, R. Fruncillo, G. Ferron, C. Roland Wolf, Quantitation of cytochrome P450 mRNA levels in human skin, Anal. Biochem. 316 (2003) 103-110.

[13] M. Saeki, Y. Saito, M. Nagano, R. Teshima, S. Ozawa, J. Sawada, mRNA expression of multiple cytochrome p450 isozymes in four types of cultured skin cells, Int. Arch. Allergy Immunol. 127 (2002) 333-336.

[14] P.M. Vyas, S. Roychowdhury, F.D. Khan, T.E. Prisinzano, J. Lamba, E.G. Schuetz, J. Blaisdell, J.A. Goldstein, K.L. Munson, R.N. Hines, C.K. Svensson, Enzymemediated protein haptenation of dapsone and sulfamethoxazole in human keratinocytes: I. Expression and role of cytochromes P450, J. Pharmacol. Exp. Ther. 319 (2006) 488-496.

[15] T.P. Dooley, R. Haldeman-Cahill, J. Joiner, T.W. Wilborn, Expression Profiling of Human Sulfotransferase and Sulfatase Gene Superfamilies in Epithelial Tissues and Cultured Cells, Biochem. Biophys. Res. Commun. 277 (2000) 236-245.

[16] C.N. Falany, D. He, N. Dumas, A.R. Frost, J.L. Falany, Human cytosolic sulfotransferase 2B1: Isoform expression, tissue specificity and subcellular localization, J. Steroid Biochem. Mol. Biol. 102 (2006) 214-221.

[17] G. Smith, M.M. Comrie, C. Roland Wolf, R.S. Dawe, C. Clark, A.T. Evans, J. Ferguson, S.H. Ibbotson, Quantitative real-time reverse transcription-polymerase chain reaction analysis of drug metabolizing and cytoprotective genes in psoriasis and regulation by ultraviolet radiation, J. Invest. Dermatol. 121 (2003) 390-398.

[18] M. Parr, G. Fusshoeller, G. Opfermann, M. Kohler, M. Hebestreit, W. Schaenzer, Synthesis of reference compounds for the identification of metabolites of 4- hydroxytestosterone, Sport Und Buch Strauß, Koln, 2005, pp. 65-74.

[19] WADA, Technical document; TD2018EAAS - Endogenous Anabolic Androgenic Steroids Measurement and Reporting, Available at: https://www.wada-ama.org/ en/resources/science-medicine/td2018eaas-0, 2018. (Last accessed 8 January 2019).

[20] WADA, Technical Document on the Minimum criteria for chromatographic-mass spectrometric confirmation of the identity of analytes for doping control purposes, Available at: https://www.wada-ama.org/en/resources/science-medicine/ td2015idcr, 2015

[21] WADA, Technical document; TD2016EAAS - Endogenous Anabolic Androgenic Steroids Measurement and Reporting, Available at: https://wada-main-prod.s3. amazonaws.com/resources/files/wada-td2016eaas-eaas-measurement-andreporting-en.pdf, 2016.

[22] P.E. Sottas, N. Baume, C. Saudan, C. Schweizer, M. Kamber, M. Saugy, Bayesian detection of abnormal values in longitudinal biomarkers with an application to T/E ratio, Biostatistics 8 (2007) 285-296.

[23] J. Mullen, A. Börjesson, O. Hopcraft, J.J. Schulze, M. Ericsson, A. Rane, M. Lehtihet, L. Ekström, Sensitivity of doping biomarkers after administration of a single dose testosterone gel, Drug Test. Anal. (2017), https://doi.org/10.1002/dta.2341.

[24] A.T. Cawley, G.J. Trout, R. Kazlauskas, A.V. George, The detection of androstenedione abuse in sport: a mass spectrometry strategy to identify the 4-hydroxyandrostenedione metabolite, Rapid Commun. Mass Spectrom. 22 (2008) 4147-4157.

[25] P. Van Renterghem, P. Van Eenoo, H. Geyer, W. Schänzer, F.T. Delbeke, Reference ranges for urinary concentrations and ratios of endogenous steroids, which can be used as markers for steroid misuse, in a Caucasian population of athletes, Steroids 75 (2010) 154-163.

[26] T. Piper, G. Fusshöller, C. Emery, W. Schänzer, M. Saugy, Investigations on carbon isotope ratios and concentrations of urinary formestane, Drug Test. Anal. 4 (2012) 942-950.

[27] M. Polet, P. Van Renterghem, W. Van Gansbeke, P. Van Eenoo, Profiling of urinary formestane and confirmation by isotope ratio mass spectrometry, Steroids 78 (2013) 1103-1109. 